NACIONES UNIDAS

AÑO INTERNACIONAL DE LA FAMILIA 2004

FAMILIES IN THE PROCESS OF DEVELOPMENT

\title{
MAJOR TRENDS AFFECTING FAMILIES IN SUB-SAHARAN AFRICA
}

\author{
BETTY BIGOMBE AND GILBERT M. KHADIAGALA
}

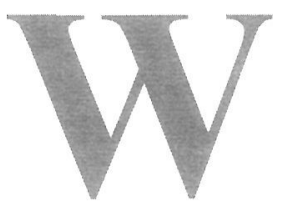

\section{INTRODUCTION}

idespread variations in geography, socioeconomic structures, and culture, cannot conceal the common opportunities and challenges that have affected African families in the last ten years since the International Year of the Family in 1994. The family as a unit of production, consumption, reproduction, and accumulation, has been profoundly impacted by the economic downturns that transformed the environment in which families make their decisions. These broader socio-political and economic environments provide the contexts for understanding changes in African family structures. Opportunities have arisen from considerable socioeconomic changes that continue to alter the structure of the family away from traditional patterns to new ones generated by the expansion of education, health care, employment, and migration. Yet the same forces that engender significant vistas for families have also produced multiple constraints. African families are embedded in political and socioeconomic circumstances that are characterized by long-standing domestic dynamics of economic fragility, debilitating poverty, poor governance and civil conflicts. Throughout the 1990s, the scourge of HIV/AIDS has put additional pressures on the sustainability of families and households. Similarly, the new demands unleashed by forces of globalization have had mixed outcomes for African families, simultaneously enhancing the chances of families to seize the opportunities for participation in larger economic exchanges while at the same time heightening their vulnerability to these forces. As a result, the state of African families is clouded by the competing strains of social regeneration and economic constraints. 


\section{CHANGES IN FAMILY STRUCTURES}

\subsection{Fertility Rates}

Fertility behavior in sub-Saharan Africa, like other parts of the world, is determined by biological and social factors. Several factors have contributed to sustain relatively high levels of fertility in most of sub-Saharan Africa. These factors include high levels of infant and child mortality, early and universal marriage, early child bearing as well as child bearing within much of the reproductive life span, low use of contraception and high social value placed on child bearing.

In the face of perceived high infant and child mortality, the fear of extinction encouraged high procreation with the hope that some of the births would survive to carry on the lineage. Interestingly, it is also believed that Rwanda's birth rate is on the increase because Rwandans generally believe it is their moral duty to replace the one million or so people that perished during the genocide.

The high value traditionally placed on marriage ensured not only its universality but also its occurrence early in life with the consequence that child bearing started early and in most cases continued until late into the productivity span. The institution of polygamy, which sometimes promotes competition for child bearing among cowives, also contributed to sustaining high fertility. Use of modern contraception was traditionally unacceptable as it violated the natural process of procreation. The traditional long period of breast-feeding and postpartum abstinence guaranteed adequate spacing between children.

Available evidence suggests that there have been changes in these socio-cultural factors over time. Age at marriage appears to have increased, though minimally; it is still relatively low in rural settings and higher in urban settings. Use of modern contraception has increased, especially use of condoms in the wake of HIV/AIDS, and improved education (especially of women) appears to have gradually eroded some of the traditional values placed on child bearing.

Changes in the structure of African families still reflect the enduring tensions between traditional and modern values and structures. Although there have been widespread accounts of families abandoning key traditional practices in favor of modern ones, the major trend remains the creation of systems of marriage and family organization that draw on both traditional and modern norms. The dominant feature of African families, as one observer notes, is its ability to "make new things out of old," and to draw forth new solutions from the traditional resources of family institutions ${ }^{1}$. As a result, the process of social adaptation of 
family organizations has produced an uneasy amalgam that is yet to crystallize into a dominant pattern. Thus the trend toward modernity has been captured in the gradual transformations of African marriage and family organizations away from corporate kinship and extended families toward nuclear households. This shift stems, in part, from the breakdown of collective, kinship-oriented systems of production and reproduction. Where nuclear households have solidified, there have equally been significant shifts from high to low fertility rates in African families. Although demographers long attributed the prevalence of high fertility rates in Africa to the resistance of indigenous socio-cultural systems to external forces, the rapid expansion of educational opportunities and availability of contraceptive methods have contributed to the emerging perception that large families are an economic burden ${ }^{2}$.

Despite significant internal differences between urban and rural settings and among African regions, the slow rates of economic growth and the mismatch between educational outcomes and labor opportunities have compelled smaller family sizes. In most urban areas, factors such as wage labor, the monetized economy and cost of living, have altered the value of children. In addition, while family networks previously mediated the negative effects of large families, resource constraints and economic decline have contributed to the reduction of family sizes and denuded the institutional structures of the extended family.

Recent research conducted using data from the World Fertility Surveys (WFS) and the Demographic and Health Surveys (DHS) reveals conclusively that in many African countries, fertility started to decline before 1975 in urban areas, and was quite advanced by 1995 ; in rural areas, fertility decline started about 10 years later. Despite variations in the speed and timing, by 1995, most African countries had lost on average about $25 \%$ (about 2 children) of original fertility levels. ${ }^{3}$ Data gathered from 19 countries in Southern, Eastern, Central and Western Africa shows that the timing of the onset of transition in

1 Therese Lauras-Lecoh, "Family Trends and Demographic Transition in Africa," International Social Science Journal, vol. 42, no. 4, 1990, p. 489.

2 Cheikh Mbacke, "Family Planning Programs and Fertility Transition in Sub-Saharan Africa," Population and Development Review, vol. 20, no. 1, 1998, pp. 188-93; Sangeetha Madhavan, "Female Relationships and Demographic Outcomes in Sub-Saharan Africa," Sociological Forum, vol. 16, no. 3, 2001, pp. 503-27; J.C. Caldwell, "Fertility in Sub-Saharan Africa," Population and Development Review, vol. 20, no. I, 1994, pp. 179-87; and J. C. Caldwell, "The Demographic Implications of West Africa Family Systems," Journal of Comparative Family Systems, vol. 27, no. 2, 1996, pp. 331-52.

3 Michele Garenne and Veronique Joseph, "The Timing of the Fertility Transition in Sub-Saharan Africa," World Development, vol. 30, no. 10, 2002, pp. 1835-1843. See also Mamta Murthi, "Fertility Change in Asia and Africa," World Development, vol. 30, no. 10, 2002, pp. 1775-1776; and Barney Cohen, "The Emerging Fertility Transition in Sub-Saharan Africa," World Development, vol. 26, no. 8, 1998, pp. 14311461. 
fertility varied significantly between urban and rural areas (Table l). For urban areas, it varied from $1.28 \%$ a year in Uganda to above $4 \%$ in Cameroon, Central African Republic and Mali. The variations were even greater in rural areas: from $0.787 \%$ a year in Namibia to above $4.0 \%$ a year in Cote d'Ivoire and Rwanda, to above $6.0 \%$ in Benin. In Kenya, where demographic data is more reliable, studies show that the speed of fertility decline has been steady: $-2.64 \%$ in urban areas, and -1.62 in rural areas. Overall, there are moderate to large declines in fertility in Kenya, Rwanda, Zimbabwe, Botswana, South Africa, and Cote d'Ivoire, with smaller declines in Malawi, Tanzania, Zambia, Cameroon, Central African Republic, Burkina Faso, Gambia, Ghana, Senegal, and Sierra Leone ${ }^{4}$.

The key explanatory variables for fertility declines revolve around the levels of urbanization and prevalence of contraceptives (Tables 2 and 3). With urbanization levels close to $50 \%$ in most African countries, cities have become the source of new lifestyles and means of access to health and contraceptive services. Despite the strong links between urbanization and the prevalence of contraceptives and reductions in fertility, surveys conducted in Kenya suggest that precipitous declines have affected all socioeconomic and demographic groups. Thus fertility has fallen in both rural and urban areas, within all age groups, and across all provinces, irrespective of socioeconomic background ${ }^{5}$. Research conducted among the Kikuyu of Central Province, Kenya, reveal significant urban-rural variations in the value of children despite aggregate fertility declines. Peri-urban areas characterized by socioeconomic changes, notably the decline in traditional agricultural systems of production and the increasing ownership of land by women, as well as education and access to contraceptives have reduced the demand for large families. Further challenging the economic value of children is the economic deterioration that has increased the costs of having many children. In contrast, high fertility rates persist in the more rural communities where social institutions and cultural practices continue to dominate and where there are fewer educational opportunities and limited use of contraceptives ${ }^{6}$.

4 Michele Garenne and Veronique Joseph, "The Timing of the Fertility Transition in Sub-Saharan Africa," World Development, vol. 30, no. 10, 2002, pp. 1835-1843.

5 Kenya National Council for Population and Development, Kenya Demographic and Health Survey, 1993. Nairobi: National Council for Population and Development, 1994 and W. C. Robinson, "Kenya Enters the Fertility Transition," Population Studies, vol. 46, no. 3, 1992, pp. 445-57.

6 Neil Price, "The Changing Value of Children Among the Kikuyu of Central Province, Kenya," Africa, vol. 66, no. 3, 2001, pp. 411-33. 
Table 1: Timing of the Fertility Transition in Sub-Saharan Africa, by country

\begin{tabular}{|c|c|c|c|c|c|c|}
\hline & \multicolumn{5}{|c|}{ ONSET OF FERTILITY } \\
\hline & & \multicolumn{3}{|c|}{ DECLINE } & \multicolumn{2}{|c|}{ SPEED } \\
\hline Country & Date of latest survey & Urban & Rural & Deviation U/R & Urban & Rural \\
\hline Benin & 1996 & 1983 & 1990 & 1983 & -3.19 & -6.33 \\
\hline Botswana & 1988 & $<1974$ & 1974 & 1960 & -2.38 & -3.49 \\
\hline Burkina Faso & 1992 & 1975 & 1986 & 1975 & -3.67 & -4.91 \\
\hline Burundi & 1987 & 1981 & & 1970 & -1.46 & \\
\hline Cameroon & 1998 & 1985 & 1993 & 1975 & -4.29 & -3.19 \\
\hline Central African Republic & 1994 & 1990 & 1990 & & -4.31 & -3.53 \\
\hline Comoros & 1996 & $<1982$ & 1987 & 1980 & -3.52 & -4.68 \\
\hline Côte d'Ivoire & 1994 & 1980 & 1990 & 1980 & -3.07 & -4.78 \\
\hline Ghana & 1993 & 1965 & 1990 & 1965 & -1.74 & -2.77 \\
\hline Kenya & 1998 & 1960 & 1970 & 1960 & -2.64 & -1.62 \\
\hline Liberia & 1986 & & & & & \\
\hline Madagascar & 1997 & 1970 & 1993 & 1970 & -2.27 & -3.02 \\
\hline Malawi & 1992 & 1982 & 1985 & 1983 & -3.29 & -2.01 \\
\hline Mali & 1996 & 1991 & 1991 & 1975 & -4.41 & -3.81 \\
\hline Mozambique & 1997 & 1984 & & 1984 & -2.59 & \\
\hline Namibia & 1992 & $<1979$ & $<1979$ & 1970 & -1.32 & -0.84 \\
\hline Niger & 1997 & 1979 & 1993 & 1984 & -1.97 & -3.23 \\
\hline Nigeria & 1999 & 1985 & 1985 & 1985 & -5.48 & -5.19 \\
\hline Rwanda & 1992 & 1981 & 1985 & 1969 & -3.59 & -4.62 \\
\hline Senegal & 1997 & 1971 & 1986 & 1971 & -1.85 & -1.81 \\
\hline Sudan & 1989 & 1964 & 1982 & 1970 & -1.81 & -6.03 \\
\hline Tanzania & 1996 & 1970 & 1977 & 1970 & -2.29 & -1.08 \\
\hline Chad & 1996 & 1988 & & 1984 & -4.22 & \\
\hline Togo & 1998 & 1970 & 1991 & 1970 & -2.14 & -3.58 \\
\hline Uganda & 1995 & 1970 & & 1970 & -1.28 & \\
\hline Zambia & 1996 & 1977 & 1977 & 1977 & -2.28 & -1.09 \\
\hline Zimbabwe & 1994 & 1970 & 1984 & 1970 & -2.78 & -4.19 \\
\hline
\end{tabular}

Source: Michele Garenne and Veronique Joseph,."The Timing of the Fertility Transition in Sub-Saharan Africa," World Development, 30(10): 1840.

Table 2: Urbanization in Sub-Saharan African Regions, 1950-2025

\begin{tabular}{|l|c|c|c|c|}
\hline & \multicolumn{4}{c}{ PERCENTAGE OF THE POPULATION IN URBAN AREAS } \\
\hline REGION & $\mathbf{1 9 5 0}$ & $\mathbf{1 9 7 5}$ & $\mathbf{1 9 9 6}$ & $\mathbf{2 0 2 5}$ (projected) \\
\hline Sub-Saharan Africa & 11 & 21 & 32 & 49 \\
Eastern Africa & 5 & 13 & 23 & 39 \\
Middle Africa & 14 & 27 & 33 & 50 \\
Southern Africa & 38 & 44 & 48 & 62 \\
Western Africa & 10 & 23 & 37 & 56 \\
\hline
\end{tabular}


Table 3: Contraceptive Prevalence in Sub-Saharan Africa, 1990s

\begin{tabular}{|c|c|c|c|}
\hline & \multicolumn{3}{|c|}{ TOTAL WOMEN USING MODERN CONTRACEPTIVES } \\
\hline REGION & $20 \%$ or higher & $10 \%$ to $19 \%$ & Less than $10 \%$ \\
\hline Eastern Africa & $\begin{array}{l}\text { Kenya } \\
\text { Zimbabwe }\end{array}$ & $\begin{array}{l}\text { Malawi } \\
\text { Rwanda } \\
\text { Tanzania } \\
\text { Zambia }\end{array}$ & $\begin{array}{l}\text { Burundi } \\
\text { Eritrea } \\
\text { Ethiopia } \\
\text { Madagascar } \\
\text { Uganda } \\
\text { Sudan } \\
\end{array}$ \\
\hline Middle Africa & & & $\begin{array}{l}\text { Cameroon } \\
\text { Central African Republic } \\
\text { Democratic Republic of Congo. } \\
\text { Congo Brazzaville }\end{array}$ \\
\hline Southern Africa & $\begin{array}{l}\text { Botswana } \\
\text { Namibia } \\
\text { South Africa }\end{array}$ & $\begin{array}{l}\text { Lesotho } \\
\text { Swaziland }\end{array}$ & \\
\hline Western Africa & & Ghana & $\begin{array}{l}\text { Burkina Faso } \\
\text { Ivory Coast } \\
\text { Gambia } \\
\text { Guinea } \\
\text { Liberia } \\
\text { Mali } \\
\text { Mauritania } \\
\text { Níger } \\
\text { Nigeria } \\
\text { Senegal } \\
\text { Togo }\end{array}$ \\
\hline
\end{tabular}

Source: Carl Haub and Diana Cornelius; Population reference Bureau 1997, World Population Data

Equally important to the broader fertility declines in Africa is the phenomenon of delayed marriage and childbearing. Demographers have established a link between delayed changes in marriage and Africa's incipient fertility transition. These trends have been captured from comparative studies of childbearing women between the ages of 20-24 and 45-49 that suggest that while most African women still marry young, the proportion of women marrying before the age of 20 has declined rapidly in most countries (Table 4). In East Africa, eight of the nine countries surveyed showed a substantial shift toward later marriages. In West Africa, two countries -Senegal and Guinea- have shown marked change between older and younger women. Other studies have reinforced this perspective, revealing the emergence of a recent trend toward later age at marriage and age at first birth in Ghana, Kenya, Nigeria, Togo, and Uganda. Although the changes in timing of marriages is attributable largely due to the positive relationship between urbanization and educational attainment, these changes are also noticeable among rural women and women with no education ${ }^{7}$. 
Table 4: Measure of Nuptiality in Sub-Saharan Africa

\begin{tabular}{|c|c|c|c|c|c|c|c|c|}
\hline \multirow{3}{*}{$\begin{array}{l}\text { COUNTRY AND } \\
\text { DATE OF SURVEY }\end{array}$} & \multicolumn{2}{|c|}{$\begin{array}{c}\text { PERCENTAGE OF } \\
\text { WOMEN MARRIED } \\
\text { BY AGE } 20\end{array}$} & \multicolumn{6}{|c|}{$\begin{array}{l}\text { MEDIAN AGE AT FIRST MARRIAGE (WOMEN } \\
25-49 \text { ) }\end{array}$} \\
\hline & \multirow{2}{*}{$\begin{array}{l}\text { Women } \\
(20-24)\end{array}$} & \multirow{2}{*}{$\begin{array}{l}\text { Women } \\
(45-49)\end{array}$} & \multirow{2}{*}{ Urban } & \multirow{2}{*}{ Rural } & \multicolumn{4}{|c|}{ Level of Education } \\
\hline & & & & & None & Primary & Secondary & Total \\
\hline \multicolumn{9}{|l|}{ EASTERN AFRICA } \\
\hline Burundi, 1987 & 44.3 & 53.7 & 18.9 & 19.5 & 19.4 & 19.8 & 22.3 & 19.5 \\
\hline Eritrea, 1995/6 & 69.5 & 79.4 & 18.0 & 16.3 & 16.2 & 17.9 & 23.9 & 16.7 \\
\hline Kenya, 1993 & 46.1 & 68.9 & 20.6 & 18.5 & 17.0 & 19.4 & 21.5 & 18.8 \\
\hline Malawi, 1992 & 76.6 & 65.9 & 18.5 & 17.6 & 17.4 & 18.1 & --- & 17.7 \\
\hline Rwanda, 1992 & 35.1 & 64.0 & 21.4 & 20.0 & 19.4 & 20.3 & 23.2 & 20.0 \\
\hline Tanzania, 1996 & 60.3 & 70.1 & 18.7 & 18.2 & 17.0 & 19.3 & -- & 18.2 \\
\hline Uganda, 1995 & 74.7 & 73.5 & 18.7 & 17.2 & 16.6 & 17.4 & 20.5 & 17.4 \\
\hline Zambia 1994 & 64.3 & 81.6 & 18.7 & 17.5 & 16.8 & 17.3 & --- & 18.0 \\
\hline Zimbabwe & 51.7 & 61.7 & 19.5 & 18.7 & 17.5 & 18.5 & 20.8 & 18.9 \\
\hline \multicolumn{9}{|l|}{ CENTRALAFRICA } \\
\hline Cameroon 1991 & 73.1 & 85.7 & 17.4 & 16.0 & 15.2 & 17.6 & 20.3 & 16.5 \\
\hline CAR 1994-95 & 73.5 & 69.6 & 16.9 & 17.6 & 17.4 & 17.0 & 17.7 & 17.3 \\
\hline \multicolumn{9}{|l|}{ SOUTHERN AFRICA } \\
\hline Botswana, 1988 & 92.5 & 81.5 & 17.3 & 17.3 & 16.9 & 17.4 & 17.9 & 17.3 \\
\hline Namibia,1992 & 20.1 & 23.1 & -- & 24.0 & 22.6 & 24.8 & -- & 24.8 \\
\hline \multicolumn{9}{|l|}{ WESTERN AFRICA } \\
\hline Benin, 1996 & 65.4 & 71.6 & 19.2 & 18.0 & 18.0 & 19.3 & 23.0 & 18.4 \\
\hline Burkina Faso, 1992-93 & 85.6 & 88.4 & 17.9 & 17.4 & 17.5 & 17.7 & 21.0 & 17.5 \\
\hline Ivory Coast, 1994 & 58.3 & 67.4 & 18.8 & 17.8 & 17.7 & 18.4 & 21.4 & 18.1 \\
\hline Ghana, 1993 & 59.7 & 59.8 & 19.5 & 18.6 & 18.5 & 18.3 & 22.3 & 18.8 \\
\hline Guinea, 1992 & 77.1 & 95.0 & 16.8 & 15.6 & 15.6 & 16.5 & 20.2 & 15.8 \\
\hline Liberia, 1986 & 64.1 & 69.5 & 18.5 & 16.8 & 16.8 & 17.3 & 20.5 & 17.5 \\
\hline Mali, 1995-96 & 82.1 & 91.2 & 17.0 & 15.8 & 15.9 & 16.6 & 20.5 & 16.0 \\
\hline Niger, 1992 & 90.1 & 92.9 & 15.4 & 15.0 & 15.0 & 17.1 & --- & 14.9 \\
\hline Nigeria, 1990 & 67.6 & 71.9 & 19.0 & 16.3 & 15.8 & 19.1 & 23.9 & 16.9 \\
\hline Senegal, 1992-93 & 59.7 & 82.5 & 18.2 & 15.7 & 15.8 & 19.3 & 23.0 & 16.2 \\
\hline Togo, 1988 & 63.0 & 66.2 & 19.7 & 17.9 & 17.8 & 18.8 & 22.5 & 18.4 \\
\hline
\end{tabular}

Source: Population Bulletin, Volume 51, No.1, April 1996.

Despite the decline in fertility, the population of sub-Saharan Africa is still expected to double within the next 22-23 years, (see Table 9). UN Population statistics identify 16 countries with a combined population of 269 million in 2000, that are expected to witness an overall quadrupling of population 2000 and 2050 , to slightly under 1 billion. 14 of these 16 countries are in Africa. The African countries in this high fertility group are: Angola, Burundi, Burkina Faso, Congo, the Democratic Republic

7 Michele Garenne and Veronique Joseph, "The Timing of the Fertility Transition in Sub-Saharan Africa," World Development, vol. 30, no. 10, 2002, pp. 1835-1843 and C. F. Westoff, Age at Marriage, Age at First Birth, and Fertility in Africa. Washington DC: World Bank Technical Paper no. 169, 1992. 
of the Congo, Ethiopia, Liberia, Malawi, Mali, Niger, Sierra Leone, and Uganda. Similarly, of the 10 countries with the highest population growth rates, 6 are in Africa: the Democratic Republic of the Congo, Eritrea, Liberia, Niger, Sierra Leone, and Somalia. Furthermore, in the 1995-2000 period, these countries had a total fertility of 5.74 children per woman, which is projected to decline to 2.51 children per woman in $2045-50^{8}$.

\subsection{Polygyny}

A critical continuity in African family patterns relates to the persistence of polygynous practices. The much-anticipated decline in polygynous households is still far from a social reality in most African countries. In rural areas, polygyny survives largely because of the imperatives established by the sexual division of labor that marks the sphere of agriculture. Multiple wives, and by extension, many children, are valued because they continue to provide essential labor services in rural agricultural production. But in most African urban areas, polygyny, once fairly common, is becoming rare, in particular among the younger generations. Comparative studies from Cameroon, Kenya, Nigeria, Sierra Leone, and Tanzania show that monogamous households have taken a greater hold on society ${ }^{9}$. Among the Igbo of Nigeria, polygyny seems to be a declining form of marriage as the strength of the conjugal relationship predominates over other family and community relationships. Young Igbo couples tend to have fewer children than their parents as knowledge and use of modern contraceptives has expanded. More importantly, increasing education, urban migration, and employment have created new courtship patterns that emphasize individual choice; these patterns, in turn, provide women with relative equality in the arena of sexuality and mate selection. These changes, however, have neither reduced the importance Igbo society places on fertility and parenthood nor altered the continuing importance of kinship networks in Nigeria. Consequently, while fertility rates have declined across generations and women have gained more decisional latitude in the family, the enduring importance of kinship rooted in African social structures continues to impose significant constraints on women's individual autonomy and choice ${ }^{10}$.

8 United Nations Population Division, World Population Prospects: The 2000 Revision, New York, 2002, p. 7.

9 Rita Schafer, "Variations in Traditional Marriage and Marriage Forms: Responses to Changing Pattern of Family-Based Social Security System in Sierra Leone and Kenya," History of the Family, vol. 27, no. 2, 1997, pp. 1-13; Dominique Meekers and Franklin Nadra, "Women's Perceptions of Polygyny Among the Kaguru of Tanzania," Ethnology, vol. 34, no. 4, 1995, pp. 315-30; and B. Adams and E. Mburugu, "Kikuyu Bridewealth and Polygyny Today," Journal of Comparative Family Studies, vol. 25, no. 2, 1994, pp. 159-66.

10 Kamene Okonjo, "Aspects of Continuity and Change in Mater-Selection Among the Igbo West of the River Niger," Journal of Comparative Family Studies, vol. 23, no. 3, 1992, pp. 339-41. 


\subsection{Single-Parenthood}

Another factor that is undermining kinship-based family structures is the prevalence of single parenthood, particularly among young urban females. As increasing numbers of women have joined the labor force, single and female-headed households have become a discernible pattern on the African social landscape" ${ }^{11}$. Although some societies continue to frown upon women over 30 who are still single, accusing them of prolonging singlehood, this new trend reflects attempts to adapt to secular changes in educational status, employment and occupational mobility, and in some cases, the decline of marriageable men. However, studies from most African cities have also shown that female-headed households are over-represented among the poor. Africa's unplanned urban sprawls are populated with unmarried single and poor women who face considerable obstacles in overcoming dislocation, migration, and deprivation ${ }^{12}$.

In South Africa, apartheid policies in many forms directly impacted family cohesion and reinforced the destructive influences that urbanization and industrialization had on the family. Thus, one consequence of the legacy of apartheid is the high number of singleparent families, resulting largely from pregnancy outside marriage and from divorce. As a large proportion of the nation's children grow up in female-headed households with little financial support, the African family in South Africa has continued to suffer considerably greater disintegration than families have in the rest of the continent. There have been links established between illegitimacy and poverty, inadequate childcare, and psychological difficulties, with enormous consequences on the downward spiral of family disintegration in South Africa ${ }^{13}$.

Coping with the circumstances of family disruption in most African countries has entailed single-parent families among lower-income groups taking their children to live with relatives, in particular, the children's grandparents. In South Africa, childcare problems and restrictions by many employers on children of their workers residing

11 P. Antonie and J. Nanitelamio, "More Single Women in African Cities; Pikine, Abidjan, and Brazzaville," Population, vol. 3, 1991, pp. 149-69.

12 Sean Jones, "Single Hood for Security: Toward a Review of the Relative Economic Status of Women and Children in Woman-Led Households," Society in Transition, vol. 30, no. 1, 1999, pp. 13-27; Sandra Wallman, Kampala Women Getting By in the Age of AIDS. London: James Currey, 1996; E. Preston-Whyte, "Women who are not Married: Fertility, 'Illegitimacy', and the Nature of the Households and Domestic Groups Among Single African Women in Durban," South African Journal of sociology, vol. 24, no. 3, 1993 , pp. 63-71.

13 E. Preston-Whyte, "Women who are not Married: Fertility, 'Illegitimacy', and the Nature of the Households and Domestic Groups Among Single African Women in Durban," South African Journal of Sociology, vol..24, no. 3, 1993, pp. 63-71. 
on their premises has strengthened the roles of African grandparents in bringing up their grandchildren. This has also reinforced the customary practices of multi-generation households where mutual support between generations guarantees the well-being of a person born into African families throughout their life cycle. Recent national surveys in South Africa indicate that the proportion of older black South Africans living in two-, three-, and four-generation households has remained fairly stable since the early nineties ${ }^{14}$. A study of 300 three-generation households in two metropolitan areas of South Africa revealed that about nine in ten African elders live in multi-generation households and that the ethos of the African extended family appears to be intact even in the urban settings. Over $80 \%$ of the top, middle and bottom generations in the 300 families studied reported harmonious relations between generations. Other studies in KwaZulu-Natal Province found that grandmothers perceive themselves as important in building families, educating younger generations, and providing generational continuity $^{15}$. A survey of rural women of KwaZulu-Natal with an average age of 51 years indicates that most of them felt empowered when they took responsibility for important family decisions including the education of grandchildren. In addition to being homemakers, the women were proud of adopting the 'traditional male' role as providers of the family if their men were unemployed ${ }^{16}$. Since the major source of funds for multigenerational support for grandchildren are pensions from grandparents, the post-apartheid South African government has continued to make transfers in the form of the state old-age pension to extended families. As a result, pensions have enhanced the status of elderly household members as income earners and provided lifelines to poorer older households ${ }^{17}$.

\subsection{Fosterage}

While the South African cases illustrate that the multi-generation African family is not on the decline, economic downturns and increased urban poverty in the rest of Africa have undermined the institution of fosterage that for long sustained the ties between rural and urban households. Fosterage constitutes part of the trend where the welfare of

14 Valerie Moller and R. Devey, "Black South African Families with Older Members: Opportunities and Constraints," Southern African Journal of Gerontology, vol. 4, no. 2, 1995, pp. 3- 10.

15 M. G. Cattell, "Zulu Grandmother's Socialization of Granddaughters," Southern African Journal of Gerontology, vol. 6, no. 1, 1997, pp. 14-16.

16 A. Sotshongaye and Valerie Moller, 1996, “My Family Eats This Money Too': Pension Sharing and SelfRespect Among Zulu Grandmothers," Southern African Journal of Gerontology, vol. 5, no. 2, 1996, pp. 9-19.

17 M. Ferreira, "Of Pensions, Caters and Homes for the Aged," Southern African Journal of Gerontology, vol. 7, no. 1,1997, pp. $1-2$. 
rural dwellers depends on their solidarity ties with urban kin families. A key component of this practice is the channeling of remittances from urban workers to rural areas through educational support. By conferring parental responsibilities to their urban relatives, fosterage guaranteed the mobility of children from rural families. Over the years, the fosterage of African children had important demographic and economic consequences. It subsidized high fertility among rural and poor families and gave poor families the means of defraying child-rearing costs. In addition, when poor and large families transferred the guardianship of their children to smaller and wealthier families, fosterage mitigated inequalities in resource endowment among children. Recent research, however, shows that the prolonged economic reversal witnessed throughout Africa has weakened fosterage networks, jeopardizing the welfare of rural families and the strength of ruralurban relationships ${ }^{18}$. A study of Cameroon shows a net decline in rural-to-urban fosterage rates during the years of its economic decline, decline that foretells a more generalized weakening of rural-urban relationships. As the economy deteriorated, was the real income of most urban households severely reduced and urban unemployment was pushed to unprecedented heights, making it impossible for urban families to support foster children. Although these changes have created more disincentives for large families in both rural and urban areas, the decline of fosterage raises concerns about the economic mobility prospects for children from rural families, especially in a climate of increased competition for limited formal-sector employment ${ }^{19}$.

\subsection{Changes in Rural Areas}

The breakdown in the symbiotic and mutually beneficial exchanges between rural and urban communities is equally matched by radical changes within rural households. This results from the collapse of the traditional African family economy in which husbands were the chief breadwinners. This economy has gradually been making way for wageearning family households whereby both the husband and wife have to strive to earn income primarily in the agricultural sector. Yet the transition to wage-earning households has occurred without corresponding shifts in power relations between the sexes, producing tensions that further

18 C. S. Stokes, "Explaining the Demographic Transition: Institutional Factors in Fertility Decline," Rural Sociology, vol. 60, no. 1, 1995, pp. 1-22; Gordon and Gordon 1996; M. Ainsworth, "Economic Aspects of Child Fostering in Cote d'lvoire," Research in Population Economics, vol. 8, 1996, pp. 25-62; ; A. K. Blanc and C. B. Lloyd, "Women's Work, Child-Bearing and Child-Rearing over the Life Cycle in Ghana," in A. Adepoju and C. Oppong, eds., Gender, Work, and Population in Sub-Saharan Africa. London: James Currey, 1994, pp. 112-31.

19 Parfait M. Eloundou-Enyegue and Shannon Stokes, "Will Economic Crises in Africa Weaken Rural-Urban Ties? Insights from Child Fosterage Trends in Cameroon," Rural Sociology, vol. 67, no. 2, 2002, pp. 1-21. 
destabilize the family. Silberschmidt's work on the Kisii in Kenya demonstrates the momentous changes in household structures as control over resources has shifted gradually away from men to women ${ }^{20}$. With rampant unemployment and dwindling resources, men's central roles as breadwinners have been redefined, making it impossible for most men to fulfill these roles. As a consequence, men have felt a loss of power, and, unable to provide for their families, they have frequently turned to alcoholism, brutality, rape, and extramarital sex for succor. In contrast, women's main role as daily household and farm managers remains in close conformity with the traditional expectations and thus they have been better able than men to achieve the social values embedded in their gender roles. Yet as men are threatened by societal changes, the persisting patriarchal structure of powers allows men to nullify women's economic contribution to the family, thus heightening poverty and marital stress.

\subsection{Policy Implications of Changes in Family Structures}

Widespread availability of economic, education, and health opportunities will continue to have remarkable influences on the changes in African family structures. What is noteworthy about these changes is the complexity, adaptability, and flexibility of family forms within their respective social and cultural contexts. Thus there is a universal consensus that policies that strengthen such adaptability remain critical to maintaining the intricate balance between traditional norms and emerging forms of family organization. In particular, there is need for policies that:

- Enhance the status and importance of women in the attainment of fertility reductions. The driving force for fertility reduction has been the ability of African women to control their reproduction, particularly in the use of contraceptives. Since the persistence of high fertility rates are correlated with minimal involvement of women in reproductive decisions, family planning schemes that empower women regarding the use of contraceptives need to be given more priority in policy plans. Successful family planning programs with strong political support invariably undermine the preference for large families $^{21}$.

20 Margrethe Silberschmidt, 'Women Forget that Men are the Masters': Gender Antagonism and SocioEconomic Change in Kisii District, Kenya. Uppsala: Nordiska Afrikainstitutet, 1999; and Silberschmidt, "Disempowerment of Men in Rural and Urban East Africa: Implications for Male Identity and SexualBehavior," World Development, vol. 29, no. 4, 2001, pp. 657-71.

21 Ezekiel Kalipeni, "The Fertility Transition in Africa," Geographical Review, vol. 86, no. 3, July 1995, p. 294. 
- In most of Africa, lower levels of infant mortality have been correlated with lower fertility rates, underscoring the importance of health programs that target prenatal and postnatal health. Because of the comparatively high childhood mortality in Africa, many families have felt the need to have more children.

- Since the prevalence of single-parent families is becoming a major trend of African families, programs targeted at enhancing the economic opportunities of single-mothers, in particular, need to be better incorporated in national plans. Most African countries do not have legislation that guarantees maternity leave for single working mothers, policies that need to be adopted to respond to the new social trend. Childcare for single mothers is also necessary to reduce the social and economic burdens on these new family forms.

- National policies to reduce the gaps between rural and urban areas should better incorporate fosterage as an essential economic and social institution. In this respect, more flexible tax policies that reward fosterage would help in alleviating the costs of fosterage for urban dwellers.

- Checking the deterioration of men's power in rural households is fundamentally an economic problem of expanding the productivity of agriculture and promoting off-farm industrial activities that create jobs that give both men and women more economic flexibility.

\section{THE RISE OF MIGRATION}

In much of Africa, internal migration forms a significant component of the livelihood systems of millions of families. For years, migration from rural to urban areas has been the essential mechanism for job opportunities, social mobility and income transfers. Nearly one third $(32 \%)$ of sub-Saharan Africans lived in urban areas in 1996, up from $11 \%$ in 1950 (see Table 2 ). The UN projects that nearly one-half ( $49 \%)$ of sub-Saharan Africa's population will be urban by $2025^{22}$. With most of Africa's urban population reaching close to 50 per cent, migration to cities continues to deepen the rural-urban ties, in particular strengthening the dependence of rural households on the remittances of migrants. The impact of urban migration on African families still reflects the abiding tensions between the imperatives of economic survival and social dislocations. In Southern Africa where urbanization is higher, the legacy of out-migration from the poorer and agrarian economies of Lesotho, Malawi, Swaziland, and Zambia to the more industrialized

22 International Migration: A Global Challenge; Population Bulletin, Vol. 51, No.1, April 1996. 
South African economy continues to have a profound impact on the structure of African families. Even though post-apartheid South Africa has gradually began to reduce dependence on migrant workers from the region, the previous migration patterns have altered the socioeconomic contexts in which households thrive ${ }^{23}$.

Studies from Swaziland show that labor migration has had corrosive effects on kinship ties. The out-migration of Swazi men to South African mines has forced women to undertake the rearing of children alone; many households lack the stabilizing influence of a father and are thus incapable of providing the support network that is the foundation of family stability. In addition, the large numbers of single women in Swaziland has increased poverty levels, yet paradoxically, while single women may be poorer, they have more control of household resources and are freer to channel more resources towards health than women who live with men ${ }^{24}$.

Nowhere are the changes on family structures felt more than in Lesotho, which is more proximate to South Africa. A recent study reveals that virtually every Lesotho household depends directly or indirectly on migrant financial monthly remittances from South Africa for survival. It is estimated that 40 per cent of the male labor force in the 20-39 age group is away in South Africa at any given time. In 1990, migrant remittances contributed 43.7 per cent of the Lesotho's GNP. Yet this positive aspect is outweighed by the far-reaching implications on the development of the family system. Out-migration has invariably led to the decline of agricultural production as wives of migrants are entrusted with subsistence farming activities. Erratic rains, drought, shortage of fertile land, and lack of markets for agricultural products have all compounded the decline. More important, one out of 10 Lesotho married men working in South Africa has abandoned his wife and taken on new ones in South Africa. Most of the abandoned wives become single parents and many of their children are not catered for adequately; moreover, abandoned wives often become the targets of married men in their societies, leading to more marriage break-ups ${ }^{25}$.

In addition, as men have migrated to low skilled jobs in South Africa, the educational profile has changed in Lesotho so that most

23 Andre Leliveld, "The Effects of Restrictive South African Migrant Labor Policy on the Survival of Rural Households in Southern Africa: A Case Study from Rural Swaziland," World Development, vol. 25, no. 1, 2001, pp. 1839-49 and G. P. Ferraro, "Marriage and Conjugal Roles in Swaziland: Persistence and Change," International Journal of Sociology of the Family, vol. 21, no. 2, 1991, pp. 89-128.

24 Andre Leliveld, "The Effects of Restrictive South African Migrant Labor Policy," p. 1843.

25 I.V.O. Modo, "Migrant Culture and Changing Face of Family Structure in Lesotho," Journal of Comparative Family Studies, vol. 32, no. 3, 2001, pp. 443-52. 
of the females left behind have acquired more education than males. These changes have in turn affected the marriage patterns whereby the educated females are less willing to get married, particularly to men in distant South African mines. Data further reveals that 32 per cent of the respondents in a survey indicated that women's superior education was responsible for the incessant marriage break-ups; 66 per cent agreed that education among women had created a new family pattern of cohabitation whereby women prefer to live with men who are not their husbands. With the escalation in bride-wealth costs, many men are marrying late, well beyond 30 years of age ${ }^{26}$.

Elsewhere in Africa, the mobility of young males in search of opportunities in urban areas remains a constant feature of migration. Women who migrate are mainly the educated, those seeking to join husbands already in towns, or the heads of the burgeoning number of single-parent families. These trends have undermined the solidity of the traditional family, created new family structures, and transferred social responsibilities at the expense of traditional institutions. The impact of migration on divorce and separation is most felt where urban males abandon their wives in rural settings. While the durability of marriages in traditional structures was strengthened by the control maintained by kinship ties, new migration patterns have increased the prospects of divorces, separation, and the opportunity for multiple partners ${ }^{27}$.In most cases, migration encourages males to have wives in the rural areas and other wives or sexual partners in urban settings. Since housing conditions in urban areas prohibit several wives to live together, "matricentric" households have emerged whereby an increasing number of households consist of a wife and children visited frequently by the husband. Although these unions represent a modern adapted version of polygyny, they contribute to family break-ups and the upsurge of female-headed households. Solidarity between spouses is weakened by separation due to migration ${ }^{28}$.

More important, the outcomes of migration movements, notably polygynous unions without regular cohabitation, have put additional pressures on the social and economic responsibilities of women. For the most part, the conditions of women have deteriorated because absent husbands who migrate to cities for a lengthy period often abdicate their economic roles. Thus overall economic changes growing from migration

26 Modo, "Migrant Culture and Changing Face of Family Structure in Lesotho," p. 449.

27 Dominique Meekers and A. Calves, “Main' Girlfriends, Girlfriends, Marriage, and Money: The Social Context of HIV Risk Behavior in Sub-Saharan Africa," Health and Transition, vol. 7, no. 1, 1997, pp. 36I75.

28 Lauras-Lecoh, Family Trends and Demographic Transition in Africa," pp. 486-87. 
have forced women to play an even greater part in providing for their children's subsistence either through food production or off-farm income-generating activities. With little means of bringing pressures to bear on their husbands, women have continued to bear most of the costs incurred in the households.

The impact of migration on African families is two-sided, precisely because of the tension between diminishing opportunities in the agricultural sector coupled with land shortages and the persistence of social norms of patriarchy. Migration is a rational response to poor employment opportunities and land hunger in rural areas, but this trend has loosened traditional social control mechanisms that regulated social reciprocities and responsibilities within families. New family structures have therefore emerged to capture

the straddling of populations between urban and rural environments. The choices of being either permanent rural residents or urbanites are open to very few Africans.

Globalization has also fostered new forms of migration as Africans seek better economic opportunities in Europe, the Middle East, and North America. The worsening economic circumstances and political instability have forced the best-educated Africans to leave home and work abroad. For the majority of these migrants, migration is part of the struggle against both debilitating poverty and implicit and explicit forms of political repression.

Africa's track record on civil war, violent conflict, strife and political instability has, with a large measure, contributed to refugee flows. By 1995 Africa contained one third of the world's refugees. About 10 million people have been the victims of forced migration ${ }^{29}$. In most cases, neighboring countries host refugees from each other (Table 5). For example, there are Mauritanian refugees in Mali, and Malian refugees in Mauritania. One of the impacts of the wars in the continent is the increasing number of widowed women, female-headed households, and orphans.

Like rural-urban migration, international migration is a doubleedged sword to families, furnishing potential economic benefits through remittances, but also breaking the social bonds of amity that sustain families. Moreover, while most international economic migrants are compelled to flee their homes for diverse reasons, many are constrained by tightened restrictions on their mobility. As governments of industrialized countries have implemented restrictive immigration policies to regulate the supply of labor from poor countries, most of the

29 UNHCR, October 1996 Report. 
Table 5: Estimated Refugee Populations in Sub-Saharan Africa as of December31, 1996

\begin{tabular}{|c|c|c|}
\hline ASYLUM COUNTRIES & REFUGEES* & SOURCE COUNTRIES \\
\hline Guinea & 650 & Liberia, Sierra Leone \\
\hline Dem Rep of Congo & 455 & Rwanda, Angola, Sudan, Burundi, Uganda \\
\hline Sudan & 395 & Eritrea, Ethiopia, Chad and Others \\
\hline Tanzania & 335 & Burundi, Rwanda, Congo, others \\
\hline Ethiopia & 326 & Somalia, Sudan, Djibouti, Kenya \\
\hline Ivory Coast & 320 & Liberia \\
\hline Uganda & 225 & Sudan, Congo, Rwanda \\
\hline Kenya & 186 & Sudan, Somalia, Ethiopia, others \\
\hline Zambia & 126 & Angola, Congo, others \\
\hline Liberia & 100 & Sierra Leone \\
\hline Senegal & 51 & Mauritania, others \\
\hline Central African Rep & 36 & Sudan, Chad, others \\
\hline Ghana & 35 & Togo, Liberia \\
\hline Niger & 27 & Mali, Chad \\
\hline Burkina Faso & 26 & Mali, others \\
\hline South Africa & 23 & Angola, Somalia, Nigeria, Congo and others \\
\hline Djibouti & 22 & Somalia, Ethiopia \\
\hline Rwanda & 20 & Congo Burundi \\
\hline Congo Brazzaville & 16 & Angola, Chad and others \\
\hline Guinea-Bissau & 15 & Mauritania, others \\
\hline Mali & 15 & Mauritania, others \\
\hline Mauritania & 15 & C \\
\hline Sierra Leone & 15 & Liberia \\
\hline Burundi & 12 & Congo, Rwanda \\
\hline Benin & 11 & Togo, Nigeria \\
\hline Togo & 10 & Ghana \\
\hline SOURCE COUNTRIES & REFUGEES* & ASYLUM COUNTRIES \\
\hline Liberia & 755 & Guinea, Ivory Coast, Sierra Leone, Ghana, Nigeria \\
\hline Somalia & 467 & Ethiopia, Kenya, Djibouti, South Africa, others \\
\hline Sudan & 434 & Uganda, Congo, Ethiopia, Central Afr Rep, Kenya, Eritrea, others \\
\hline Sierra Leone & 350 & Guinea, Liberia \\
\hline Eritrea & 343 & Sudan, others \\
\hline Burundi & 285 & Tanzania, Congo, Rwanda \\
\hline Rwanda. & 257 & Congo, Tanzania, Uganda, Burundi \\
\hline Angola & 220 & Congo, Zambia, Congo Brazzaville, South Africa, Namibia \\
\hline Dem Rep of Congo & 117 & Tanzania, Uganda, Zambia, Rwanda, Burundi, Angola, S. Africa \\
\hline Mali & 80 & Burkina Faso, Niger, Mauritania, Algeria \\
\hline Mauritania & 65 & Senegal, Mali \\
\hline Etiopia & 58 & Sudan, Kenya, Djibouti \\
\hline Togo & 30 & Ghana, Benin \\
\hline Senegal & 17 & Guinea-Bissau, Gambia \\
\hline Chad & 15 & Central Afr Rep, Sudan, Congo Brazza, Niger, Nigeria \\
\hline Niger & 15 & Algeria \\
\hline Uganda & 15 & Congo \\
\hline Djibouti & 10 & Ethiopia \\
\hline Ghana & 10 & Togo \\
\hline
\end{tabular}

* Number of Refugees (1000s).

Note: Table includes countries with 10,000 or more refugees.

Source: US Committee for Refugees: World Refugee Survey 1997 
migrants become either illegal or have few opportunities of employment ${ }^{30}$. Despite the restrictions on migration, the rising numbers of able-bodied men and women who are found washing up on the shores of the Mediterranean Sea demonstrate the determination of migrants to reach Europe.

To underscore the enormity of this problem, UNICEF has estimated that cross-border smugglers in Central and West Africa enslave 200,000 children a year. Traffickers tempt victims with job offers and offers of adoption in wealthier countries. They in turn keep them in subservience through physical violence, debt bondage, passport confiscation, and threats of violence against their families ${ }^{31}$. These insidious forms of "migration" are thriving on the margins of globalization as African states lose the ability to control and police the activities of economically powerful non-state actors.

Table 6: Migrant Sending and Receiving Regions, 1990-1995

\begin{tabular}{|c|c|c|c|}
\hline \multicolumn{2}{|c|}{ REGION } & NET MIGRANTS (thousands) & RATE (per 1,000 population) \\
\hline \multirow{15}{*}{ 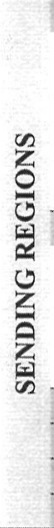 } & AFRICA & -63 & -0.1 \\
\hline & - Eastern & -128 & -0.6 \\
\hline & - Central & 4 & 0.1 \\
\hline & - Northern & 69 & 0.5 \\
\hline & - Southern & 2 & 0.04 \\
\hline & -Western & 0.1 & 0.01 \\
\hline & ASIA & -1.366 & -0.4 \\
\hline & - Eastern & -171 & -1 \\
\hline & - South Central & -664 & -5 \\
\hline & - Southeastern & -485 & -11 \\
\hline & - Western & -46 & 0.03 \\
\hline & LATIN AMERICA & -392 & -0.9 \\
\hline & CARIBEAN & -99 & -2.9 \\
\hline & CENTRAL AMERICA & -202 & -1.7 \\
\hline & SOUTH AMERICA & -91 & -3 \\
\hline \multirow{9}{*}{ 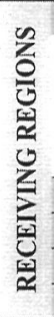 } & EUROPE & 739 & 1 \\
\hline & - Eastern & -109 & 0.04 \\
\hline & - Northern & 47 & 5 \\
\hline & - Southern & -20 & -1 \\
\hline & - Western & 821 & 4.6 \\
\hline & NORTH AMERICA & 971 & 3.4 \\
\hline & OCEANIA & 111 & 5.8 \\
\hline & AUSTRALIA-NEW ZEALAND & 122 & 5.8 \\
\hline & OTHER OCEANIA & -11 & -1.7 \\
\hline
\end{tabular}

Source: UN, World Population Prospects, the 1994 Revision (New York, UN 1995): 128.

30 Aderanti Adepoju, "Recent Trends in International Migration in Sub-Saharan Africa," International Social Science Journal, vol. Vol. 52, no. 2, 2000, pp. 383-94

31 UNICEF, The State of The World's Children. New York: UNICEF, 2000; and Asmita Naik, "Protecting Children from Protectors: Lessons from West Africa," Forced Migration Review, vol. 15, October 2002, pp. $16-19$ 


\section{DEMOGRAPHIC AGEING, RETIREMENT AND ITS SOCIO- ECONOMIC IMPACT}

Africa has been greatly impacted by global ageing against the backdrop of deterioration of social and family support systems that once sustained older persons. UN Population statistics show that the proportion of older persons in Africa will likely double from 5 per cent to 10 per cent over the next 50 years ${ }^{32}$. The aged in Africa have traditionally found care within the informal structures of the family. Inter-generational income transfers from the young to the old did provide, for the most part, the sole means of economic security in old age. The traditional care systems in Africa were rooted in complex family patterns that included reciprocal care and assistance among the generations, with older persons being not only on the receiving end, but also fulfilling meaningful active roles. Although emotional ties and economic support remain strong in Africa in comparison with industrialized countries, economic decline and social breakdown have consigned older persons to poverty and marginalization ${ }^{33}$. Moreover, national governments have not developed appropriate social welfare policies that cater to the rapidly ageing populations. Consequently, with social welfare typically occupying a low priority at national levels, the burdens of caring for older persons have gravitated even more to resource-constrained families.

Even in relatively affluent South Africa with a developed pension system for most of its urban workers, the quality of life of older persons has deteriorated over the years because of poverty and inadequate housing. Some South African communities have attempted to mitigate the social strains on older persons by emphasizing multi-generation households. A study in KwaZulu Natal shows, for instance, that grandmothers with pensions have added value to society by taking care of their families even if they were widowed and no longer able to hold down a job ${ }^{34}$. Similarly, other urban communities have launched pilot schemes where able older persons are paid to provide childcare in a well-funded setting; these schemes utilize the skills of older persons and keep them as active participants in the communities in which they live. Unique to South Africa, these schemes have enhanced a culture

32 United Nations Population Division, World Population Prospects: The 2000 Revision, New York, Department of Economic and Social Affairs, p. 15.

33 Nana Araba Apt, "Ageing and the Changing Role of the Family and Community: An African Perspective," International Social Security Review, vol. 55, no. 2, 2002, pp. 39-47; and Apt, Coping with Old Age in a Changing Africa. London: Aldershot, 1996.

34 A. Sotshongaye and Valerie Moller, "My Family Eats This Money Too",, p. 14..S. Van Der Berg, "Ageing, Public Finance, and Social Security in South Africa," Southern African Journal of Gerontology, vol. 7, no. 1,1998 , pp. 3-7 
of caring, in which the community and family take responsibilities for older persons and are willing to play an active role through voluntary organizations in assisting the less fortunate ${ }^{35}$.

Table 7: List of Social Security Programs in Sub-Saharan Africa, By Type

\begin{tabular}{|c|c|c|c|c|c|}
\hline COUNTRY & $\begin{array}{l}\text { Old age survivors } \\
\text { and disability }\end{array}$ & $\begin{array}{c}\text { Sickness and } \\
\text { maternity }\end{array}$ & $\begin{array}{c}\text { Workers' } \\
\text { compensation }\end{array}$ & $\begin{array}{c}\begin{array}{c}\text { Unemployment } \\
\text { insurance }\end{array} \\
\end{array}$ & $\begin{array}{c}\begin{array}{c}\text { Family } \\
\text { allowances }\end{array} \\
\end{array}$ \\
\hline Benin & $\mathrm{x}$ & & $\mathrm{x}$ & & $\mathrm{x}$ \\
\hline Botswana & & & $\mathrm{x}$ & & \\
\hline Burkina Fasso & $\mathrm{x}$ & & $\mathrm{x}$ & & $\mathrm{x}$ \\
\hline Burundi & $\mathrm{x}$ & & $\mathrm{x}$ & & $\mathrm{x}$ \\
\hline Cameroon & $\mathrm{x}$ & & $\mathrm{x}$ & & $x$ \\
\hline Eritrea & & & & & \\
\hline Central Afr Rep. & $\mathrm{x}$ & & $\mathrm{x}$ & & $\mathrm{x}$ \\
\hline Chad & $\mathrm{x}$ & & $\mathrm{x}$ & & $\mathrm{x}$ \\
\hline Congo Brazzaville & $\mathrm{x}$ & & $\mathrm{x}$ & & $\mathrm{x}$ \\
\hline Ivory Coast & $\mathrm{x}$ & & $\mathrm{x}$ & & $\mathrm{x}$ \\
\hline Ethiopia & $\mathrm{x}$ & & $\mathrm{x}$ & & \\
\hline Gabon & $\mathrm{x}$ & & $\mathrm{x}$ & & $\mathrm{x}$ \\
\hline Gambia & $\mathrm{x}$ & & $\mathrm{x}$ & & \\
\hline Ghana & $\mathrm{x}$ & & $\mathrm{x}$ & & \\
\hline Guinea & $\mathrm{x}$ & & $\mathrm{x}$ & & $\mathrm{x}$ \\
\hline Kenya & $\mathrm{x}$ & & $\mathrm{x}$ & & \\
\hline Liberia & $\mathrm{x}$ & & $\mathrm{x}$ & & \\
\hline Madagascar & $\mathrm{x}$ & & $\mathrm{x}$ & & $\mathrm{x}$ \\
\hline Malawi & & & $\mathrm{x}$ & & \\
\hline Mali & $\mathrm{x}$ & & $\mathrm{x}$ & & $\mathrm{x}$ \\
\hline Mauritania & $\mathrm{x}$ & & $\mathrm{x}$ & & x \\
\hline Mauritius & & & $\mathrm{x}$ & & $\mathrm{x}$ \\
\hline Mozambique & & & & & \\
\hline Namibia & & & & & \\
\hline Níger & $\mathrm{x}$ & & $\mathrm{x}$ & & $\mathrm{x}$ \\
\hline Nigeria & $\mathrm{x}$ & & $\mathrm{x}$ & & $\mathrm{x}$ \\
\hline Rwanda & $\mathrm{x}$ & & $\mathrm{x}$ & & $\mathrm{x}$ \\
\hline Senegal & $\mathrm{x}$ & & $\mathrm{x}$ & & $\mathrm{x}$ \\
\hline Sierra Leone & & & $x$ & & \\
\hline Somalia & & & $\mathrm{x}$ & & \\
\hline South Africa & $x$ & $\mathrm{x}$ & $\mathrm{x}$ & $\mathrm{x}$ & $\mathrm{x}$ \\
\hline Sudan & $\mathrm{x}$ & & $\mathrm{x}$ & & \\
\hline Swaziland & $\mathrm{x}$ & & $\mathrm{x}$ & & \\
\hline Tanzania & $\mathrm{x}$ & & $\mathrm{x}$ & & $\mathrm{x}$ \\
\hline Togo & $\mathrm{x}$ & & $\mathrm{x}$ & & $\mathrm{x}$ \\
\hline Uganda & $\mathrm{x}$ & & $\mathrm{x}$ & & \\
\hline DR Congo & $\mathrm{x}$ & & $\mathrm{x}$ & & $\mathrm{x}$ \\
\hline Zambia & $\mathrm{x}$ & & $\mathrm{x}$ & & \\
\hline Zimbabwe & $\mathrm{x}$ & & $\mathrm{x}$ & & \\
\hline
\end{tabular}

Source: Social Security Programs Throughout the World(1997), Social Security Administration, Office of Research and Statistics. Research Report \# 65.

35 S. Van Der Berg, "Ageing, Public Finance, and Social Security in South Africa," Southern African Journal of Gerontology, vol. 7, no. 1, 1998, pp. 3-7; and Valerie Moller, "Innovations to Promote an Intergenerational Society for South Africa to Promote the Well Being of the Black African Elderly," Society in Transition, vol. 29, no. 1, 1998, pp. 1-11. 
Furthermore, urbanization has had a negative effect on the support mechanisms that dealt with older persons. Urban living means that the old and the young are no longer living in the same households; modern arrangements have destroyed the key social welfare features that provided for intergenerational support. There is a gender dimension to the precarious nature of older persons in Africa. Studies throughout the region reveal that the number of older women living in isolation has increased owing to the outward migration of children to urban areas; more older women than men consider their status within the family to have deteriorated primarily because of widowhood and economic dependency. In old age, widowed women in Africa often live on the margins of communities that are equally impoverished ${ }^{36}$.

The scale of marginalization is more evident in rural areas where the social protection of older persons has eroded because of increasing poverty, lack of infrastructure such as health care, education, and social services. Inequalities experienced early in life, in particular access to education and health care, have critical bearings on the status and well being of the aged. Because of urbanization, the young generations who traditionally catered to older persons have migrated to cities, leaving the aged behind in rural areas. Yet few urban dwellers have the means to maintain the care of the rural aged. In addition, mandatory retirement programs that are common throughout Africa relegate the aged to the rural areas without adequate economic opportunities. A study of the transformation of care of the aged in Kenya captured their social isolation and squalid conditions. The increase in the aged population has been accompanied by economic strains that have reduced the ability of families to cope. Although the government has made rhetorical commitments to addressing the plight of older persons, there are very few institutions that care for the aged. Moreover, most of older persons living in such institutions are opposed to them because they alienate them from their families. Consequently, a bulk of older persons feel isolated, bored, and limited in their interactions with other members of the community ${ }^{37}$.

\subsection{Policy Implications concerning Ageing and Older Persons}

The challenge facing African countries is how to design intergenerational support systems that would integrate the older population back into mainstream social life. This would mitigate the

36 World Bank, Averting the Old Age Crisis: Policies to Protect the Old and Promote Growth. New York: Oxford University Press, 1994.

37 M. A. Nyangweso, "Transformations of the Aged Among Africans: A Study of the Kenyan Situation,"Aging and Mental Health, vol. 2, no. 3, 1998, pp. 181-85. 
consequences of urban migration and rural poverty and help reduce the debilitating impact of marginalization of the vulnerable populations. Although innovative programs such as South Africa's that strengthen the bonds linking older persons to the family, the broader problem for older persons lies in socioeconomic programs that replace the fast declining traditional care systems. Adequate food, housing, and healthcare are essential in later life. Yet the attainment of these essentials hinges on the gradual reduction of poverty and social exclusion as key elements of any policy that foster social integration of older persons. Comprehensive programs meeting these needs should proceed from the recognition that in African societies, the welfare of older persons cannot be detached from that of society as a whole ${ }^{38}$. Hence policies ought to focus on:

- Integration of socioeconomic concerns of older persons in broader national budgetary and development plans;

- Encouraging mutual assistance programs in both urban and rural areas that seek to expand the opportunities of pensioners and retirees;

- Supporting poverty reduction programs in rural areas that specifically address the plight of older persons;

- Providing tax incentives to community programs undertaken by older persons and their families that support the enhancement of income security;

- Supporting rural assistance programs that focus on widows, as the most vulnerable group among older persons;

- Supporting urban community childcare programs that draw from the labor and experiences of the growing population of the aged;

- Fostering broad-based national socioeconomic programs that promote the quality of life of older citizens;

- Encouraging economic policies that reduce the marginalization of rural communities that have most of the older populations.

\section{THE IMPACT OF HIV/AIDS}

Twenty years after evidence of a mysterious new disease first appeared in the medical literature, HIV/AIDS continues its devastating march across sub-Saharan Africa. It is now the leading cause of death on the continent. It has already claimed the lives of more than 18 million 
Africans. In the year 2001 alone, two million people died as a result of HIV/AIDS - ten times the death toll of all the continent's conflicts combined. (see Table 8). Another 28 million Africans are living with HIV/AIDS today, the vast majority of them in the prime of their lives as workers and parents. In 16 countries, more than one of every ten adults is HIV-positive. Despite promising developments over the past year, the situation is growing worse. More than 10,000 Africans are newly infected each day, nearly four million every year. If effective action is not taken, the Joint United Nations Program on HIV/AIDS (UNAIDS) estimates that 40 percent of today's 15 -year-olds will ultimately acquire HIV in countries such as Ethiopia and Côte d'Ivoire, and 60 percent in countries such as South Africa and Zambia.

Sub-Saharan Africa has suffered the greatest impact of any region thus far because it was struck first, it started from a base of weak public health infrastructure, and it has not mounted an adequate response. Some countries - notably Senegal and Uganda- have stemmed or reversed the spread of the epidemic. But most have not, despite having national HIV/AIDS programs. Their efforts have fallen short for several reasons: there has been insufficient government commitment and leadership; programs have been inadequately financed; support from the international community has been too slow, especially in scaling up or replicating programs that have proven effective; not enough resources have reached communities or civil society, which implement some of the most successful activities; and programs have been too narrowly focused.

Most of those infected are in the age group 20 to 49 years and the overwhelming majority are parents. Furthermore, the overwhelming majority of all those infected do not know they are infected. Many women are indirectly diagnosed when they are still well through the diagnosis of HIV infection in their children. Many men do not get diagnosed until they have a clinically observable HIV-related illness. In most households where there is one infected person, there will probably be three or more: both parents and one or more children.

The AIDS epidemic has had far reaching effects on family. Many of the most striking images of the HIV epidemic are of families, but of unfamiliar families: female-headed family, grandparent surrounded by grandchildren, adolescent-headed families, often siblings and cousins bonded together, dying adults tended by their children and communities as families try to support victims of HIV/AIDS. The age group most affected occupies a critical position in families and communities: as heads of households, the labor force and leaders in society. HIV infections cluster in families in which both parents are often HIV- 
positive, placing enormous strains on the capacity of families to cope with the psychological and economic consequences of the illness. Consequently, there has been a progressive disintegration of families, as they become ineffective social and economic units. As AIDS devastates the traditional support systems for older persons, the latter are forced to take on the burdens of child care under conditions of increasing personal impoverishment.

AIDS has also exacted a particularly heavy toll on young women. Sub-Saharan Africa is the only region where more women than men are HIV-positive. In some countries, rates among girls aged 15-19 are 5 to 6 times higher than among boys in the same age group. A host of factors account for the greater prevalence among women, including economic dependence, limited autonomy and bargaining power, legal marginalization, certain cultural practices, social notions of masculinity, low educational attainment, and the lack of female-controlled prevention methods.

AIDS is also creating unprecedented social welfare challenges: it has already orphaned about 14 million African children, the number is likely to double by 2010 . Before the spread of HIV, roughly 1 in 50 children in developing countries was orphaned. Today the proportion has reached 1 in 6 in the hardest-hit countries, a share unparalleled in recorded history. This is likely to push the age dependency ratio well above 1.0 and is already placing extreme strains on coping mechanisms ${ }^{39}$.

\subsection{Economic Factors}

In economic terms the epidemic has already reversed many development gains of the past generation and now threatens to undermine the next. Its developmental impact has only begun to be felt and could persist for decades. Cross-country regressions suggest that AIDS is already costing sub-Saharan Africa an estimated 0.7-1.0 percent of per capita growth each year. In the worst hit countries, World Bank models have projected that by 2010 AIDS may reduce aggregate output by $15-$ 20 percent, and per capita consumption by nearly 10 percent. UNAIDS estimates that the annual loss in Gross Domestic Product (GDP) growth per person as a result of AIDS is estimated to be $0.8 \%$ by 2010 . For example, in Uganda, (one of the most highly affected countries) estimates of the National Strategic Framework for HIV/AIDS activities for the period 2000/1-2005/6 indicate that the cost of interventions will be equivalent to the entire annual health budget of Ush. 227 billion $^{40}$

39 "The Spread and Effect of HIV-1 Infection in Sub-Saharan Africa," Lancet, vol. 359, no. 9322, August 2002 , pp. $2-7$

40 US $1=1795$ Uganda shillings 
Table 8: HIV Prevalence in Countries in Sub-Saharan Africa

Countries worst affected by HIV/AIDS

(prevalence rates $>4 \%$ of adult population at end 1999)

\begin{tabular}{l|r|r|r|r} 
COUNTRY & $\begin{array}{c}\text { ADULT } \\
\text { RATES (\%) }\end{array}$ & $\begin{array}{c}\text { ADULTS AND } \\
\text { CHILDREN }\end{array}$ & $\begin{array}{c}\text { ADULT } \\
\text { 49) }\end{array}$ & $\begin{array}{c}\text { (15- } \\
\text { ORPHANS }\end{array}$ \\
CUMULATIVE
\end{tabular}

Source: Alan Whiteside, "Poverty and HIV/AIDS in Africa," Third World Quarterly, vol. 233, no. 2, 2002, p. 315 .

(without taking into account the cost of anti-retroviral therapy and drugs for treatment of opportunistic infections). While average monthly household income is estimated at Ush.31,500/-, AIDS related expenditures were Ush.35,000/- for burial and Ush.70,000/- for the medical costs of a terminal patient. A survey in Rakai district, (one of the most affected districts in the country) found that $65 \%$ of the households had to sell property to cover the cost of AIDS care ${ }^{41}$.

AIDS reduces productivity, depletes scarce public and private capacity, raises the cost of doing business, exacerbates gender inequality, deepens poverty, diminishes school enrollment, overwhelms health systems, impairs human rights, weakens food security, erodes social capital, and progressively crowds out government development investments. AIDS is jeopardizing development investments in all sectors. 
In Southern Africa, AIDS has worsened food shortages in Lesotho, Malawi, Mozambique, Swaziland, Zambia, Zimbabwe, and some parts of South Africa. According the UN Food and Agricultural Organization (FAO), the disease will cut agricultural labor by nearly a quarter in Zimbabwe by 2020 , when 23 per cent of Zimbabwe's agricultural worker's will have died. Mozambique is expected to lose 20 per cent and Malawi 14 per cent of agricultural workers. Overall, crop production by small-scale and subsistence farmers throughout the region has been affected by the sickness, time spent looking after sick relatives, and loss of income ${ }^{42}$.

Gender inequality and diminished education will help fuel the continued spread of HIV, driving a vicious circle. Unless the epidemic is addressed more forcefully, it will be impossible for Africa to attain the majority of the Millennium International Development Goals.

The cumulative effect of the epidemic on determinants of social welfare include:

- Sickness and death caused by HIV/AIDS causes a decline in individual and household productivity leading to food insecurity, family disintegration and weakening of the traditional family system for orphan care

- The health system is being stretched by the need to care for people with AIDS, and there is still a large gap in funding to meet the full needs of a scaled-up care and prevention program. For example in Uganda in costs between \$2 $-\$ 4$ per person for a visit

- The number of AIDS orphans is estimated at $15 \%-20 \%$ of the total population in most Eastern and Southern African countries. Before parents die, these children usually cared for their sick parents causing psychologically traumatized children in most cases.

- The quality of care-giving, education, nutrition and socialization is often poor for children with parents who are bed-ridden or dead.

- The teaching profession, one of the linchpins of African development, has been disproportionately impacted by the HIV/AIDS epidemic. In Central African Republic, for instance, 107 schools closed in 2000 because of teacher shortages, largely due to AIDS. In Zambia, in the first 10 months of 1998, an estimated 1,300 teachers died-twothirds the number of new teachers trained annually. And in Botswana, mortality among primary school teachers has increased by 60 per cent since 1998. 
HIV/AIDS affects entire family units consisting of women and their children, and extended families. The increasing loss of people due to AIDS undermines social and economic development gains achieved in the past. It is reversing gains in child survival as it is increasing the mortality rate of infants and children. It places enormous stress on infected individuals and their families who are confronted with the demands of caring for the seriously ill and with the trauma of death. In addition, they also face the economic burdens of health care and funeral costs, as well as the loss of income when the breadwinner becomes ill.

Consequently HIV/AIDS changes family structure and function. The problems for the family start before a member dies. At the loss of the breadwinner, women, children, older persons or single parents are usually left to run households, with severe implication for those concerned. Women and female-headed households are particularly vulnerable to the impact of HIV/AIDS. At the same time, women, girls tend to bear the burden of caring for the sick family member, and often have less care and support when they themselves are infected. The disturbing trend of HIV/AIDS is the growing number of orphans, and the increasing number of child-headed households.

\subsection{Socio-Economic Impact of HIV/AIDS on Rural Families}

Preliminary studies conducted indicate that HIV/AIDS affect men and women quite differently. According to the studies conducted by UNDP, in Uganda, 1997, the socioeconomic impact of the epidemic on rural families has different repercussions depending on whether it is the $\mathrm{man} /$ father or woman/mother who dies. The findings reveal that more women have lost their husbands to AIDS than men who have lost their wives. This is because polygamy is still being practiced. The common practice by men who have single wives is to remarry almost immediately after the death of the HIV-infected wife thereby transferring the infection to the new spouse and responsibility for the care of the children as well. Although it is not often that the children remain with the new wife (because they are often mistreated or discriminated against), more often than not a new home would be found for them, usually of the maternal aunt or of the grandparents.

\subsection{The Status of Widows}

Women whose husbands die of AIDS are usually younger and thus tend to have dependants who need to be looked after. Irrespective of whether husbands die of HIV/AIDS or other causes, widows in subSaharan Africa generally face the following problems: 
- They risk having their properties, including land, confiscated as they do not have the right to inherit land, and sometimes they even lose the right to use land, unless the husband has left a will;

- They may be inherited by the late husband's brother or close male relative;

- They have sole responsibility for the children;

- They suffer a significant loss of income and support services and these affect their standard of living;

- They are usually overworked, have little time to themselves and are thus hard to reach and mobilize.

The HIV epidemic often pushes women whose husbands have died of AIDS and their families below the poverty threshold, directly threatening the survival and well-being of their families. Femaleheaded-households affected by AIDS become entrenched in poverty, as, in addition to the loss of labor and cash income, women have fewer legal rights than men, are often less literate than men, and have less access to support services, credit and inputs. The result is a marked increase in poverty among AIDS widows. This feminization of poverty, a key characteristic of the socio-economic impact of the HIV/AIDS epidemic, has far reaching consequences particularly for youths, with girls/young women being most affected. Given the prevalence of the disease, the marked increase in poverty among young women and their dependants is likely to have a profound impact on this region as a whole, particularly on food security, as it is women who are mainly responsible for food production.

\subsection{Status of AIDS Orphans}

In the wake of AIDS, a second human tragedy is unfurling:.a massive number of orphans unparalleled in human history. The longterm legacy of HIV/AIDS is the growth in the number of orphans who lose one or both parents, or caregivers. UNAIDS estimates that by the end of 2000 about 13 million children in sub-Saharan Africa under age fifteen would have lost their mother or both parents to AIDS. By 2010 the number of orphans is projected to increase to 35 million $^{43}$. The US Census Bureau also predicts that by 2010 , in five countries in east and Southern Africa alone, over $30 \%$ of all children under age fifteen will be orphans, largely due to AIDS.

The impact of the HIV/AIDS epidemic on orphans depends on a number of factors, including the socio-economic status of their families, 
the size of the family and their age. Losing parents to AIDS means that children have to assume new roles and new responsibilities within the nuclear as well as the extended family. Traditional roles, duties and responsibilities of family members become blurred, as AIDS places additional demands and pressures on orphans, particularly economic uncertainty, stigmatization and emotional insecurity. The following trends have been observed:

- Children whose parents die of AIDS in towns are usually taken back to the rural areas. They have to adapt to loss of parent(s) as well as to rural life. The security and stability of their family life is disrupted and there is no social safety net or mechanism to help children through this transition period. Education ceases, thereby increasing risk behavior among the older orphans especially girls. If both parents have died, the orphans are dispersed to various relatives. The disintegration of the family often means the children may not grow up in a family and will not receive attention and guidance from relatives. Grandparents might find it difficult to discipline and control young adults.

- In some cases, some orphans may run away from home or from the extended family home to escape poverty that AIDS-afflicted and affected families are subjected to.

- Some children might be sent to a town or abroad to make up for the loss of income and help support younger siblings.

- It is also reported that the drop out rate in school among orphans is high because most of them cannot afford school fees and uniforms and some drop out because of stigma; absenteeism is equally high because some orphans have to attend to household chores; failure is also reported to be high.

- A huge number of children without parental guidance spell trouble for the future ${ }^{44}$.

\subsection{The Impact of HIV/AIDS on the Household Economy and the Fa-} mily Value System

The impact of HIV/AIDS ranges from breakdown to disintegration of family, depending on whether one or both parents have died. The following coping mechanisms emerge:

- Having already depleted meager resources and savings for costly treatment and funerals, the family suddenly finds itself deprived of

44 J. Sengando and J. Nambi, "The Psychological Effects of Orphan hood: A Study of Orphans in Rakai District," Health Transition Review, vol. 10, 1997, pp. 105-24; and "Children Orphaned by AIDS: A New Challenge," Population Reports, vol. 29, no, 3, 2001, pp. 1-8. 
labor, cash income and access to credit, as well as support services. The surviving spouse is faced with a situation to improvise for the loss of income. In widow-headed household children are unattended, meals are poorly and hastily prepared and the widow's own health and diet deteriorate as a result of exhaustion and less food intake. Older children help with household chores and with agricultural activities. Children who have lost both parents are likely to work longer hours than children who have lost one parent and remain in the nuclear home.

- HIV/AIDS victims' families may be stigmatized and/or ostracized - the AIDS stigma can sever the support widows and orphans would otherwise have from the extended family and the community. Stigmatization usually results in loss of respect within the extended family and community. Land area under cultivation may be reduced because of labor shortages. Loss of access to labor in the land may result in declining agricultural productivity that in combination with loss of cash income often leads to deterioration of the quality of household diet and reduction in the number of meals. .

\subsection{Early Marriage/Unions and Childbearing}

It is also reported that young men and women are getting married, or raise families without being officially married, at increasingly younger age. One of the reasons cited is the rising cost of living and the economic value of women. The bride price, which the groom has to pay for the bride, is getting prohibitive. Early marriage means early realization of economic value of a daughter and parents who are struggling to raise many children may choose to marry their adolescent daughters earlier than they would have in different circumstances. The reason for the crisis within the family is largely attributed to new pressure caused by the epidemic. Of course there are other factors like war, displacement of people, break-up of families, rape, death, and poverty that all contribute to the erosion of traditional courtship, marriage, and erosion of social fabric as a whole.

The socio-economic impact of HIV/AIDS is beginning to have an effect on the value system of the family, as traditional norms and customs are breaking down under the pressures of the epidemic.

\subsection{Policy Implications of HIV/AIDS}

In order to tackle the daunting tasks to deal with the complexity of the problems faced by families in the wake of HIV/AIDS here are some challenges that need to be addressed: 
- Long -term policies that select to change paternalistic institutions and that may end women's economic dependency on men.

- Policies to correct occupational segregation, gender inequality, and feminization of poverty.

- Support to orphans of AIDS and other vulnerable children (children that are caring for terminally ill parents, and children caring for their siblings).

- More involvement of men in HIV prevention.

- Formulation and implementation of policies to provide care to families with HIV.

- Creation of family-coordinated AIDS care that meets the complex needs of infected women and their families.

- Forging HIV/AIDS education policies that straddle abstinence, faithfulness, and condom-use domains.

- High-level leadership and political commitment in HIV/AIDS campaigns across Africa.

- International donor commitment to support countries that acknowledge HIV/AIDS as a threat to national development and security.

\section{THE IMPACT OF GLOBALIZATION}

Globalization for Africa has had mixed results, deepening its opportunities to participate in world-wide markets and accessing new technologies, yet further diminishing the possibilities for meaningful integration into this economy. The dilemma revolves around what some observers have described as double marginalization: the continent's absolute decline in relation to the global economy; and the widening socioeconomic disparities in countries that have taken advantage of globalization ${ }^{45}$. The gradual erosion in Africa's share of global trade and Foreign Direct Investment (FDI) has widened the pockets of poverty and deepened income inequalities among African countries and between Africa and the rest of the world. Africa's share of global trade accounted for only 1.6 per cent in the 1990s; the gross national product for subSaharan Africa is less than 10 per cent of the United States ${ }^{46}$. Added

45 David Apter, "Globalization and Its Discontents: An African Tragedy," Dissent, vol. 49, no. 2, Spring 2002, pp. 13-18 Samir Amin, "Africa: Living on the Fringe," Monthly Review, vol. 53, no. 10, March 2002, pp. 41-51; and Frederick Cooper, "What is the Concept of Globalization Good for? A Historical Perspective," African Affairs, vol. 100, no. 399, April 2001, pp. 189-214.

46 David Apter, "Globalization and Its Discontents: An African Tragedy," p. 14. 
to this dismal picture are heavy indebtedness, inefficient investment, inadequate services, poorly performing state corporations, low labor productivity, urban unemployment, declining agricultural production, weak administrative and health facilities, and eroding educational standards. All these factors lead to fragile infrastructures, corruption, a dearth of skilled workers, and poor economic diversity.

Africa's economic travails in the global division of labor were exacerbated since the 1980s by the onset of the Structural Adjustment Policies (SAPS) forced upon a majority of African countries by international financial institutions. Internally, SAPS heightened social inequalities within Africa, putting pressure on families, in particular women and children, even as the African state declined as a meaningful actor in the economic arena. The enormous pressures of liberalization advanced by international financial institutions to make African economies more competitive invariably reduced the ability of individual states to provide the wide array of socioeconomic safety nets that prevailed in the $1970 \mathrm{~s}$ and $1980 \mathrm{~s}^{47}$. Mounting criticisms against the impact of SAPS in Africa led to belated shifts in lending policies to target poor and vulnerable groups, partially mitigating the social costs of adjustments. Subsequent policy platforms by international actors such as promotion of good governance in conjunction with economic liberalization, anti-poverty crusades, and mainstreaming gender in development, belie the enormous obstacles to redressing the everwidening global and national inequalities.

Critics of the governance agenda of global financial institutions have, for instance, noted that there has been a progressive erosion of democratic governance through trade liberalization that has had devastating consequences for families ${ }^{48}$. In addition to weakening the state as the arena of local contests over the production and distribution of goods and services, globalization has led to the decline of Africa's already-weak manufacturing sectors through open trading regimes. Throughout Africa, this has greatly affected jobs in urban settings, reducing the economic capacity of family sustenance. Globalization promises that higher labor costs in developed countries will steadily lead to the migration of low-skilled jobs to Africa, but this has yet to occur because of political instability, relative geographic isolation, and inadequate infrastructures ${ }^{49}$. The paradox of globalization for Africa is

47 Samir Amin, Africa: Living on the Fringe," pp.48-49.

48 N. Folbre, "Debating Business: Women and Liberalization at the Council for Foreign Relations," Signs: Journal of Women in Culture and Society, vol. 26, no. 4, 2001, pp. 1259-63.

49 Asfaw Kumssa, "Globalization and Regionalization: Implications for Developing Countries," Regional Development Dialogue, vol. 19. no. 2, Autumn, 1998, pp. 7-16 
starkly illustrated by the fact that its economies need to be securely integrated into global markets, primarily through private investment, but this integration exacerbates the problems globalization is supposed to solve. Private investment in the high technology sector employs relatively few workers, hence increasing rather than decreasing patterns of social inequalities. Furthermore, the 1990s revealed that marketdriven reforms produce marginality, social disruption, and political turbulence, expanding opportunities for the few without a corresponding enlargement of opportunities for the many ${ }^{50}$.

The tendency of globalization to deepen inequalities in African countries that have embraced it is more instructive to families because these differences affect the household more visibly. Recent developments in commodity and labor markets associated with the process of globalization have posed new uncertainties for rural people dependent on agriculture. One of the major stumbling blocks at the Seattle, Quebec City, and Doha meetings of the World Trade Organization (WTO) was the liberalization of trade in agriculture. Rich country governments are opposed to such liberalization; instead they prefer to carve out farm products as an exception to free trade, so that their politically powerful agricultural sectors do not have to compete with poorer countries. Toward that end, rich countries lavish $\$ 300$ billion on their farmers every year, an amount that is more than the national incomes of all of sub-Saharan Africa ${ }^{51}$. To improve the lives of the rural poor eking out livings through agriculture requires removing, not adding, trade barriers.

As the agricultural sector in Africa has declined through years of government neglect and the new global trade barriers, households have tried to diversify their resource base to cope with market demands and minimize income insecurity. In the prevailing circumstances, agriculture alone no longer provides a secure and sustainable living for rural people, even for those who own relatively large land holdings. Hence a majority of them need predictable sources of cash earnings to maximize household livelihood security ${ }^{52}$. This has inevitably spawned male migration in search of work in national or international labor markets, leaving women to take over the work on the land or the nonfarm family business. But male migration in insecure urban labour markets

50 David Apter, "Globalization and Its Discontents," p. 14.

51 Kenneth Karl, "World Trade: Africa Seeks to Enhance its Role," The Courier, no. 185, March-April 2001, pp. 16-18; Anne-Marie Mouradian, "A New WTO is Launched, "The Courier, no. 190, January-February 2002, pp. 6-8; Ferial Haffajee, "Doha Diary: Developing Countries Stand Strong," The Courier, no. 190 , January-February 2002, pp. 9-12.

52 T. Straubhaar and A. Wolter, "Globalization, Internal Labor Markets, and Migration of Highly Skilled," Intereconomics, vol. 32 , no. 4, 1997, pp. 174-80. 
hardly compensates for the deterioration in incomes; the redundancies in labor-intensive sectors, especially among the unskilled and poorly educated, guarantees that there are no obvious benefits to migration. Consequently, in both rural and urban areas, the effects of globalization have continued to marginalize the labor and resource needs for human reproduction, thereby marginalizing women and the poor $^{53}$.

In some African countries, there have been challenges to the reach of globalization particularly from women's groups protesting their marginalization. In Tanzania, for instance, instead of accepting the power of the global economy, women tried to create alternative formal and informal collective strategies through the use of social networks in the wake of the government's diminishing economic role $^{54}$. More dramatically, women in Nigeria's oil-producing Niger Delta have physically blocked the access of oil workers to production sites, protesting environmental degradation and the exclusion of their children from employment in these companies ${ }^{55}$. These emerging local challenges in Africa are partly emboldened by the diverse, albeit growing transnational civil society movements that are contesting various facets of globalization. In the sphere of women's rights, the global feminist network DAWN (Development Alternatives with Women for a New Era) has been since 1987 at the forefront championing the development of organizational capacities among women to improve the lot of their families ${ }^{56}$. One of the positive elements of globalization is the ability of marginalized groups to tap into the substantial resources of such transnational actors.

Ultimately, however, in the absence of fair and just global rules, globalization will increase the ability of the strong to advance their interests to the detriment of the weak especially in the area of trade, finance and technology. Africa's inability to harness the process of globalization results from structural impediments to growth and development in the form of resource outflows and unfavorable terms of trade. To mitigate the gross inequalities and the concentration of the benefits fostered by globalization, African countries have recently embarked on program, the New Partnership for Africa's Development (NEPAD) that seeks aid and debt relief from the developed economies in exchange for universal

53 “Measuring Globalization: Who's Up, Who's Down? Foreign Policy, no. 134, January-February 2003, pp. $1-13$.

54 S. Bergeron, "Political Economy Discourses of Globalization and Feminist Politics," Signs: Journal of Women in Culture and Society, vol. 26, no. 4, 2001, pp. 983-1006.

55 Charmaine Pereira, "Configuring 'Global,' 'National,' and 'Local' in Governance Agendas and Women's Struggles in Nigeria," Social Research, vol. 69, no. 3, Fall 2002.

56 Charmaine Pereira, "Configuring 'Global,' 'National,' and 'Local' in Governance Agendas and Women's Struggles in Nigeria," p. 800. 
norms of good governance and economic performance. Following the Group of 8 summit in Canada in 2002, donor nations pledged \$6 billion annually by 2006 that would help Africa achieve 7 per cent annual economic growth and reduce the number of people living in poverty by half by the year 2015 .

Table 9: Population growth in Sub-Saharan Africa, 1970-1980, 1980-1992

\begin{tabular}{|c|c|c|}
\hline \multirow{2}{*}{ COUNTRY } & $1970-1980$ & $1980-1992$ \\
\hline & $\begin{array}{l}\text { Average Annual Population } \\
\text { Growth rate (\%) }\end{array}$ & $\begin{array}{c}\text { Average Annual Population } \\
\text { Growth rate (\%) }\end{array}$ \\
\hline Sub-Saharan Africa & 2.8 & 3.0 \\
\hline Botswana & 3.7 & 3.4 \\
\hline Benin & 2.7 & 3.1 \\
\hline Burkina Faso & 2.1 & 2.6 \\
\hline Cameroon & 2.9 & 2.8 \\
\hline Central African Rep & 2.2 & 2.6 \\
\hline Chad & 2.0 & 2.4 \\
\hline Ivory Coast & 4.0 & 3.8 \\
\hline Congo & 2.8 & 3.1 \\
\hline Etiopía & 2.6 & 3.1 \\
\hline Gabon & 4.6 & 3.4 \\
\hline Ghana & 2.2 & 3.2 \\
\hline Kenya & 3.7 & 3.6 \\
\hline Lesotho & 2.3 & 2.7 \\
\hline Mali & 2.1 & 2.6 \\
\hline Mauritania & 2.4 & 2.4 \\
\hline Mauritius & 1.5 & 1.1 \\
\hline Malawi & 3.1 & 3.2 \\
\hline Niger & 2.9 & 3.3 \\
\hline Nigeria & 2.9 & 3.0 \\
\hline Rwanda & 3.3 & 2.9 \\
\hline Sierra Leone & 2.1 & 2.4 \\
\hline Somalia & 2.9 & 3.1 \\
\hline South Africa & 2.7 & 2.5 \\
\hline Sudan & 2.9 & 2.7 \\
\hline Tanzania & 2.9 & 3.0 \\
\hline Zambia & 3.0 & 3.2 \\
\hline Zimbabwe & 2.9 & 3.3 \\
\hline
\end{tabular}

Source: World Bank 1994

To meet these goals, Africa would still need to fill an annual resource gap of about $\$ 64$ billion, much of it from domestic sources ${ }^{57}$. NEPAD envisages that domestic resource mobilization will come from increased national savings by firms and households, effective tax collection, rationalizing government expenditure, and reversing capital

57 Declaration on the Implementation of the New Partnership for African Development (NEPAD), Durban, South Africa, July 2002; Kempe Ronald Hope, "From Crisis to Renewal: Towards a Successful Implementation of the New Partnership for African Development," African Affairs, vol. 101, no. 404, July 2002, pp. 387 402; and Ernest Harsch, "Africa Still Waiting for Genuine 'Partnership'," Africa Recovery, vol. 16, no. 2-3, September 2002, pp. 26-28. 
flight by improving the conditions for domestic investments. To ensure that economic development is meaningful to the already deteriorating conditions of African families, NEPAD has urged signatories to pay special attention to improving the physical infrastructure, especially roads, railways and power systems; human development, focusing on health and education, including skills development; agriculture; and promoting the diversification of production and exports, with a focus on market access to industrialized countries. Framers of NEPAD acknowledge that Africa's long-term development needs to be anchored in the determination of African people to "extricate themselves and the continent from the malaise of underdevelopment and exclusion in a globalizing world ${ }^{58}$. Calling for a new relationship between Africa and the international community, NEPAD foresees a context in which nonAfrican partners seek to complement Africa's own efforts.

\section{REFERENCES}

ADAMS, B. and MBURUGU, E. 1994. "Kikuyu Bridewealth and Polygyny Today," Journal of Comparative Family Studies, vol. 25, no. 2, pp. 159-66.

ADERANTI ADEPOJU. 2000. "Recent Trends in International Migration in Sub-Saharan Alrica," International Social Science Journal, vol. Vol. 52, no. 2, pp. 383-94.

AINSWORTH, M. 1996. "Economic Aspects of Child Fostering in Cote d'Ivoire," Research in Population Economics, vol. 8, pp. 25-62.

AMIN, S. 2002. "Africa: Living on the Fringe," Monthly Review, vol. 53, no. 10, pp. $41-51$.

ANKRAH, M. 1993. "The Impact of HIV/AIDS on the Family and Other Significant Relationships: The African Clan Revisited," AIDS Care, no. 5,.pp. 5-22.

ANTONIE, P. and NANITELAMIO, J. 1991. "More Single Women in African Cities; Pikine, Abidjan, and Brazzaville," Population, vol. 3, pp. 149-69.

ARABA, N. Apt. 1996. Coping with Old Age in a Changing Africa. London: Aldershot.

ARABA, N. Apt and GRIECO, M. 1994. "Urbanization, Caring for the Elderly People and Changing African Family: The Challenges to Social Policy," International Social Security Review, vol. 47, no. 1, pp. 3-4.

ARABA, N. Apt. 2002. "Ageing and the Changing Role of the Family and Community: An African Perspective," International Social Security Review, vol. 55, no. 2, pp. 39-47.

APTER, D. 2002. "Globalization and Its Discontents: An African Tragedy," Dissent, vol. 49, no. 2, pp. 13-18.

BERGERON, S. 2001. "Political Economy Discourses of Globalization and Feminist Politics," Signs: Journal of Women in Culture and Society, vol. 26, no. 4, pp. 983-1006.

BLANC, A.K. and LLOYD, C.B. 1994. "Women's Work, Child-Bearing and Child-Rearing over the Life Cycle in Ghana," in A. Adepoju and C. Oppong, eds., Gender, Work, and Population in Sub-Saharan Africa. London: James Currey, pp. 112-31.

CALDWELL, J.C. 1994. "Fertility in Sub-Saharan Africa," Population and Development Review, vol. 20 , no. 1 , pp. $179-87$.

58 NEPAD Declaration on Democracy, Political, Economic, and Corporate Governance, Lusaka, Zambia, July 2001. 
CALDWELL, J.C. 1996. "The Demographic Implications of West Africa Family Systems," Journal of Comparative Family Systems, vol. 27, no. 2, pp. 331-52.

CATTELL, M.G. 1997. "Zulu Grandmother's Socialization of Granddaughters," Southern African Journal of Gerontology, vol. 6, no. 1, pp. 14-16.

COHEN, B. 1998. "The Emerging Fertility Transition in Sub-Saharan Africa," World Development, vol. 26 , no. 8 , pp. 1431-1461.

COOPER, F. 2001. "What is the Concept of Globalization Good for? A Historical Perspective," African Affairs, vol. 100, no. 399, pp. 189-214.

ELOUNDOU-ENYEGUE, P.M. and STOKES, S. 2002. "Will Economic Crises in Africa Weaken Rural-Urban Ties? Insights from Child Fosterage Trends in Cameroon," Rural Sociology, vol. 67 , no. 2, pp. 1-21.

FERREIRA, M. 1997. "Of Pensions, Caterers, and Homes for the Aged," Southern African Journal of Gerontology, vol. 7, no. 1, pp. 1-2.

FERRARO, G.P. 1991. "Marriage and Conjugal Roles in Swaziland: Persistence and Change," International Journal of Sociology of the Family, vol. 21, no. 2, pp. 89-128.

FOLBRE, N. 2001. "Debating Business: Women and Liberalization at the Council for Foreign Relations," Signs: Journal of Women in Culture and Society, vol. 26, no. 4, pp. 1259-63.

GARENNE, M. and JOSEPH V. 2002. "The Timing of the Fertility Transition in Sub-Saharan Africa," World Development, vol. 30, no. 10, pp. 1835-1843.

HAFFAJEE, F. 2002. "Doha Diary: Developing Countries Stand Strong," The Courier, no. 190, pp. 9-12.

HARSCH, E. 2002. "Africa Still Waiting for Genuine 'Partnership'," Africa Recovery, vol. 16, no. 2-3, pp. 26-28.

HEINECKEN, L. 2002. "Living in Terror: The Looming Security Threat to Southern Africa," African Security Review, vol. 10, no. 4, p. 9.

HOPE, K.R. 2002. "From Crisis to Renewal: Towards a Successful Implementation of the New Partnership for African Development," African Affairs, vol. 101, no. 404, pp. 387-402.

JONES, S. 1999. "Single Hood for Security: Toward a Review of the Relative Economic Status of Women and Children in Woman-Led Households," Society in Transition, vol. 30, no. 1, pp. 13-27.

KALIPENI, E. 1995. "The Fertility Transition in Africa," Geographical Review, vol. 86, no. 3, p. 294.

KARL, K. 2001. "World Trade: Africa Seeks to Enhance its Role," The Courier, no. 185, pp. 1618.

Kenya National Council for Population and Development. 1994. Kenya Demographic and Health Survey, 1993. Nairobi: National Council for Population and Development.

KUMSSA, A. 1998. "Globalization and Regionalization: Implications for Developing Countries," Regional Development Dialogue, vol. 19. no. 2, pp. 7-16.

LAURAS-LECOH, T. 1990. "Family Trends and Demographic Transition in Africa," International Social Science Journal, vol. 42 , no. 4, pp. 483-99.

LELIVELD, A. 2001. "The Effects of Restrictive South African Migrant Labor Policy on the Survival of Rural Househoids in Southern Africa: A Case Study from Rural Swaziland," World Development, vol. 25, no. 1, pp. 1839-49.

MADHAVAN, S. 2001. "Female Relationships and Demographic Outcomes in Sub-Saharan Africa," Sociological Forum, vol. 16, no. 3, pp. 503-27.

MBACKE, C. 1998. "Family Planning Programs and Fertility Transition in Sub-Saharan Africa," Population and Development Review, vol. 20, no. 1, pp. 188-93. 
MEEKERS, D. and NADRA, F. 1995. "Women's Perceptions of Polygyny Among the Kaguru of Tanzania," Ethnology, vol. 34, no. 4, pp. 315-30.

MEEKERS, D. and CALVES, A. 1997. "Main' Girlfriends, Girlfriends, Marriage, and Money: The Social Context of HIV Risk Behavior in Sub-Saharan Africa," Health and Transition, vol. 7 , no. 1, pp. 36175 .

MODO, I.V.O. 2001. "Migrant Culture and Changing Face of Family Structure in Lesotho," Journal of Comparative Family Studies, vol. 32, no. 3, pp. 443-52.

MOLLER, V. 1998. "Innovations to Promote an Intergenerational Society for South Africa to Promote the Well Being of the Black African Elderly," Society in Transition, vol. 29, no. 1, pp. 1-11.

MOLLER, V. and DEVEY, R. 1995. "Black South African Families with Older Members: Opportunities and Constraints," Southern African Journal of Gerontology, vol. 4, no. 2, pp. 3-10.

MOURADIAN, A-M. 2002. "A New WTO is Launched", The Courier, no. 190, pp. 6-8.

MURTHI, M. 2002. "Fertility Change in Asia and Africa," World Development, vol. 30, no. 10, pp. 17751776.

NAIK, A. 2002. "Protecting Children from Protectors: Lessons from West Africa," Forced Migration Review, vol. 15, pp. 16-19.

NEPAD. 2001. Declaration on Democracy, Political, Economic, and Corporate Governance, Lusaka, Zambia.

NEPAD. 2002. Declaration on the Implementation of the New Partnership for African Development (NEPAD), Durban, South Africa.

NYANGWESO, M.A. 1998. "Transformations of the Aged Among Africans: A Study of the Kenyan Situation," Aging and Mental Health, vol. 2, no. 3, pp. 181-85.

OKONJO, K. 1992. "Aspects of Continuity and Change in Mate-Selection Among the Igbo West of the River Niger," Journal of Comparative Family Studies, vol. 23, no. 3, pp. 339-41.

PRESTON-WHYTE, E. 1993. "Women who are not Married: Fertility, 'Illegitimacy', and the Nature of the Households and Domestic Groups Among Single African Women in Durban," South African Journal of Sociology, vol. 24, no. 3, pp. 63-71.

PEREIRA, C. 2002. "Configuring 'Global,' 'National,' and 'Local' in Governance Agendas and Women's Struggles in Nigeria," Social Research, vol. 69, no. 3, pp. 782-804.

PRICE, N. 2001. "The Changing Value of Children Among the Kikuyu of Central Province, Kenya," Africa, vol. 66, no. 3 pp. 411-33.

ROBINSON, W.C. 1992. "Kenya Enters the Fertility Transition," Population Studies, vol. 46, no. 3, pp. 445-57.

SEN, G. 1992. "Globalization, Justice, and Equity: A gender Perspective," Development, vol. 40, no. 2,.pp. 21-26.

SENGANDO, J. and NAMBI, J. 1997. "The Psychological Effects of Orphan-hood: A Study of Orphans in Rakai District", Health Transition Review, vol. 10, pp. 105-24.

SCHAFER, R. 1997. "Variations in Traditional Marriage and Marriage Forms: Responses to Changing Pattern of Family-Based Social Security System in Sierra Leone and Kenya," History of the Family, vol. 27, no. 2, pp. 1-13.

STRAUBHAAR, T. and WOLTER, A. 1997. "Globalization, Internal Labor Markets, and Migration of Highly Skilled," Intereconomics, vol. 32, no. 4, pp. 174-80.

SILBERSCHMIDT, M. 1999. Women Forget that Men are the Masters': Gender Antagonism and Socio-Economic Change in Kisii District, Kenya. Uppsala: Nord-iska Afrikainstitutet. 
SILBERSCHMIDT, M. 2001. "Disempowerment of Men in Rural and Urban East Africa: Implications for Male Identity and Sexual Behavior," World Development, vol. 29, no. 4, pp. 657-71.

SOTSHONGAYE, A. and MOLLER, V. 1996. "My Family Eats This Money Too': Pension Sharing and Self-Respect Among Zulu Grandmothers," Southern African Journal of Gerontology, vol. 5, no. 2, pp. 9-19.

STOKES, C.S. 1995. "Explaining the Demographic Transition: Institutional Factors in Fertility Decline," Rural Sociology, vol. 60, no. 1, pp. 1-22.

United Nations Population Division. 2003. World Population Prospects: The 2000 Revision, New York, Department of Economic and Social Affairs.

UNAIDS. 2000. Report on the Global HIV/AIDS Epidemic. New York: UNAIDS.

UNICEF. 2000. The State of The World's Children. New York: UNICEF.

VAN DER BERG, S. 1998. "Ageing, Public Finance, and Social Security in South Africa," Southern African Journal of Gerontology, vol. 7, no. 1, pp. 3-7.

WALGATE, R. and CULLINAN, K. 2002. "HIV/AIDS Deepens Food Crisis in Southern Africa," Bulletin of the World Health Organization, vol. 20.

WALLMAN, S. 1996. Kampala Women Getting by in the Age of AIDS. London: James Currey.

WESTOFF, C.F. 1992. Age at Marriage, Age at First Birth, and Fertility in Africa. Washington

DC: World Bank Technical Paper no. 169.

WHITESIDE, A. 2002. "Poverty and HIV/AIDS in Africa," Third World Quarterly, vol. 233, no. 2.

World Bank. 1994. Averting the Old Age Crisis: Policies to Protect the Old and Promote Growth. New York: Oxford University Press. 